\title{
A REFLECTION ON THE INDEPENDENCE OF INDEPENDENT AGENCIES
}

\author{
JAMES C. MILLER, III*
}

Independent agencies should not be independent. I believe that for policy as well as for constitutional reasons.

When I was Chairman of the Federal Trade Commission (FTC), I often posed to myself the following question: "To whoin am I accountable?" Often, it seeined, the answer would be: "To 435 Congressmen, 100 Senators, and the President himself!" On many occasions, lowever, the answer would be: "As long as I apply a modicum of discretion, I am accountable to no one." This answer, I submit, is evidence of a najor institutional defect, for it means that at least one official, with rather broad latitude for public good or public liarm, occasionally did not feel accountable. Sucli a situation would be far less likely if the official sin question had been inore closely supervised by the President and his assigns.

In addition to insufficient accountability, there are other policy reasons why I believe the independence of independent agencies is a bad idea. Consider the problem of policy coordination. In the area of antitrust, for example, there is a compelling need for the FTC to coordinate its policies with those of the Antitrust Division of the Department of Justice. While a considerable amount of such coordination does go on, the Commission lias been reluctant to get involved in certain pertinent, though higher-level, executive branch policy activities. (I remember well the objections raised by Pennsylvania Senator Arlen Specter to the FTC's representation on a White House working group coordinating commercial policy.)

A related shortcoming of "independence" is that independent agencies liave "no place at the table" when it coines to formulating policies that directly affect the agency. It is difficult enough for non-cabinet executive agencies to feel fully informed and to be represented in the highest levels of government decisionmaking. But the independent agencies liave

* Director, Office of Management and Budget (1985 to present). Chairman of the Federal Trade Commission (1981 to 1985), Member of the Council of the Administrative Conference (1981 to present), and Vice Chairman of the Administrative Conference (1987 to present). The views expressed are the author's own and do not necessarily represent formal positions of the administration. 
little voice in such deliberations nor the efficient means to gather information from such proceedings.

Let me hasten to point out that thus far I've been reflecting upon the executive functions of independent agencies. Of course, when agenciesindependent or otherwise-engage in adjudicatory functions, I behieve that strict independence must be maintained.

As for the constitutional reasons why independence is a bad idea, I shall leave it to those trained in the law to elucidate. Suffice it to say, however, that INS v. Chadha ${ }^{1}$ and its progeny would appear to shake the foundation of the house of cards built upon Humphrey's Executor $v$. United States. 2

A few additional observations. First, in my experience, "outside contacts" froin government officials that were (or bordered upon being) improper were almost always generated at the Capitol Hill end of Pennsylvania Avenue rather than at the White House end. In the vast majority responding to soine constituent's plea and not realizmg the sensitivity of the contact (with my office). Thus, I developed a quick and ready response whenever such a call was received. It went like this: "Congressman (or Senator), before you get into that, I'm sure you must be calling ine about the merits of the issue, not the pohtics. And smce you are calling ine about the inerits, I think it vitally inportant that you place all such inaterials in the public record. Let ine assure you that we will give due consideration to any and all views that may be pertinent to this case. Of course, we will have to make our judgment on the merits in each instance." Not inconsistent with this pohicy, I would always, "as a favor," agree to visit with anyone a Congressinan or Senator insisted that I meet. I would also hear their pitch. But I refused to give any "special consideration" to their "connections" and courteously communcated the same to any congressional caller.

Beyond a number of "outside contacts" with regard to specific matters, I encountered a plethora of congressional (and a few executive) pressures-some of which were constructive in that they reinforced the notion of accountability, but most were not. The head of an independent agency must be especially vigilant to protect the prerogatives of the agency against vested interests. Being outside the shelter and protection afforded by the President, independent agency officials are more open to "hits" by ineinbers of Congress and the media. With a far greater frequency than that experienced by executive officials, appointees to in-

\footnotetext{
1. 462 U.S. 919 (1983).

2. 295 U.S. 602 (1935).
} 
dependent agencies are fair game for congressional theatrics and their supporters in the inedia. While that is to be expected ("it goes with the job"), it ineans that independent agencies must be especially resilient and careful in order to maintain inorale and the credibility necessary for efficient functioning. (Of course, one way of ameliorating this problein is to eliminate the distinction between executive and independent agencies.)

In conclusion, I beheve it would be wise to eliminate coinpletely the distinction afforded independent agencies. The executive as well as adjudicatory functions of independent agencies can be accoinphished perfectly well by executive officials serving at the pleasure of the President. 